\title{
Indian Waters: Past and Present
}

\author{
Senthil Kumar Kurunthachalam*
}

Department of Natural Sciences, Savannah State University, Savannah, GA 31404, USA

\begin{abstract}
Water is a natural resource, a basic necessity to living things including humans and wildlife, food production, food security, sustainable development and alleviate the poverty of the country. Despite of having blessed with enormous water resources (e.g., Mt. Himalaya's originated Holy River Ganges, and its several tributaries from the north, Kaveri River in the south, ever rain forests [e.g., Mousinram near Cherrapunji], world's tastiest waters of the Siruvani River in Coimbatore, Western Ghats Basin, network of fresh water resources etc.,), "water problem" is huge 'a big threat and cross cut problem in India'. Due to hectic population increase and drinking water consumption, decreased rainfall, the 'water problem' in India is becoming a major threat. Particularly, water pollution, poor sanitation, dwindling/decrease in rainfall, groundwater levels and water scarcity designs the world's second most populous nation. Water is most essential for livelihoods, agriculture, energy production, industrial development and for several other potential consumptions. In India, 'water problems' arise mainly due to poor management, negligence, in appropriate technology and poor responsibility by the peoples and needed to be taken special precautionary measures. Consequently in this paper some major issues related to Indian waters during the past and currently have been reviewed and highlighted.
\end{abstract}

Keywords: Indian waters; Water resources; Water borne disease; Water quality; Water pollution; Indian rivers; Sanitation

\section{Introduction}

India is one of the fastest developing countries (e.g., economic growth of $6.4 \%$ in between $2010-2011$ [ $10^{\text {th }}$ largest by nominal GDP and $3^{\text {rd }}$ largest by purchasing capabilities]) despite of the facts such as largest democratic population on the earth along with differences in language, culture, lifestyle, religion belief, etc., The geographical area of India covers $3,287,590$ sq.km., with the coastline length of 7,500 $\mathrm{km}$. India's human population of 1.2 billion covered about $17 \%$ of the earth's total population. Particularly, 740 million people living in and around rural areas of India with 1.6 million habitations and also with more than 14 diverse ecological habitats [1-3]. India has the largest rural drinking water supply program in the world serving almost more than 740 million people. Nevertheless, health status for the majority of the Indians is far from the satisfaction when compared to the developed nations $[4,5]$. Every year over 38 million Indians is shown to infect with waterborne diseases. Other statistics revealed over 1.4 million school children dies due to diarrhea and therefore almost 74 million working days are lost each year because school going children in India is largest especially in rural regions with almost 6.4 million schools $[1,6]$. The National Family Health Survey (NFHS) showed a $75 \%$ of children at the age of 6-14 years are attending schools in rural areas [1]. Based on these facts the economic burden in India calculated to be $\$ 600$ million/year [6]. Considering those all aforesaid backgrounds, India is the center of the attraction for the water related issues and should be closely monitored on a timely basis and all the existing problems should be addressed immediately. If it is not performed, it will be hard for India to achieve a dream of World Class health care delivery program in this largest democracy.

\section{Water Resources in India}

Although water has different forms of solid state such as ice, and gas state such as water vapor/steam, the significant use of water refers to liquid state. On the earth's surface water covers $71 \%$ of the total mass in which oceans alone contributes more than $97 \%$ of the total area. Furthermore, water available as a glacier/ice (e.g., Antarctic ice sheet contributes more than $85 \%$ of fresh water on the earth followed by Arctic) of about $2.4 \%$ followed by below ground water of $1.6 \%$ (particularly as aquifers) and surface water (e.g., rivers, lakes and ponds) of $0.6 \%$. Only $0.001 \%$ of water found in the air as vapor, clouds (formed of solid and liquid water particles suspended in air) and rainfall. As it is indicated that India covered almost $17 \%$ of the world's population, its requirement of fresh water resources is $4 \%$. India has a rich water resource containing a network of rivers $[3,7-$ 11] average annual flow/year is estimated at $1953 \mathrm{~km}^{3}$ [8] and also blessed with snow cover of the Himalaya Mt., further, Western Ghats plateau also provides a water requirement of the country. In India, major rivers are River Ganges (including Yamuna Sub-Basin), Kaveri, Indus (e.g., Satluj and Beas), the Brahmaputra, Godavari, Narmadha, Mahanadhi, Krishna, Brahmini (e.g., Baitarni Sub- Basin), Sabarmati, Pennar, Mahi and Tapi. Among them, highly polluted rivers (in terms of highly toxic organic and inorganic compounds and bacteria, virus, fungi, protozoa, parasites) are classified as the Ganges and its subbasin Yamuna, Kaveri, Indus (only Satluj), Godavari, Mahanadhi, Krishna, Brahmini Sabarmati and Tapi [12]. However, relatively clean rivers such as the Brahmaputra, Narmadha, Indus (only Beas), Pennar and Mahi serves comparatively clean water [12]. India has the pride of having the world's second tastiest "Siruvani Water" in Coimbatore city, Tamil Nadu state after the Nile. Nevertheless, more than $70 \%$ of India's surface water (utilizable resources are $692 \mathrm{~km}^{3} /$ year [8]) and groundwater (utilizable resources are $396 \mathrm{~km}^{3} /$ year [8]) have been polluted seriously by chemicals, biological pathogens and other forms (e.g., biological oxygen demandingsubstances, suspended solids/matter, inorganic plant nutrients, thermal pollution or genetic

*Corresponding author: Senthil Kumar Kurunthachalam, Department of Natural Sciences, Savannah State University, Savannah, USA, E-mail: kuruntha@gmail.com

Received January 09, 2013; Accepted January 11, 2013; Published January 14 2013

Citation: Kurunthachalam SK (2013) Indian Waters: Past and Present. Hydro Current Res S10: 001. doi:10.4172/2157-7587.S10-001

Copyright: (C) 2013 Kurunthachalam SK. This is an open-access article distributed under the terms of the Creative Commons Attribution License, which permits unrestricted use, distribution, and reproduction in any medium, provided the original author and source are credited. 
pollution). The river pollution occurs mainly due to rapid increase in the industrial development and human population and the necessity to meet the increasing demands of agricultural needs, domestic consumption as well as discharge of untreated sewage [13-17].

Despite is being the fastest developing country, India has poorly managed waterways. Among the developed countries, water leakage (which is not available for billing) is estimated to be $<3 \%$. On the other hand in India, water leakage/pilferage is $45 \%$ at most [1]. This is a very big loss for the government and a huge threat to the sustainable development of the country. The official estimates indicate that surface and ground water availability is around 1,869 billion cubic meters (BCM) in India. From this, $40 \%$ cannot be used due to geological and topographical reasons and loss. Only about 4,000 BCM of fresh water is available due to precipitation in the form of rain and snow, most of which returns to the seas (river carries it) [1]. From the available water resources $92 \%$ of the "ground water" pumped is used in the agricultural sector, 5\% and 3\% respectively, employed for industrial and domestic purpose. Similarly $89 \%$ of available "surface water" is used for agricultural sector $2 \%$ and $9 \%$ respectively, were used for the industrial and domestic purpose [1]. The sources indicate that $80 \%$ of Indian drinking water requirement is obtained from the groundwater which is depleted by severe chemical contamination $[7,18]$. Therefore, it is also expected that by around 2020, India will be a "water stressed" country with per capita availability declining to 1,600 cubic meter/ person/year. A country is said to be water stressed when the per capita availability of water drops below 1,700 cubic meters/person/year [2].

Clean, fresh drinking water is essential to human and all other life forms on the earth. Access to safe drinking water has improved steadily and substantially over the last decades in almost every part of the world. However, some observers have estimated that by 2025 more than half of the world population will be facing water-based vulnerability [8]. A study in 2009 suggests that by 2030 , in some developing regions of the world, water demand will exceed by $50 \%$ which is suitable to India $[8,14-17,19]$. The rainfall in India shows very high spatial, sporadic and temporal variability and paradox of the situation is that Mousinram near Cherrapunji, which receives the highest rainfall in the world, also suffers from a shortage of water during the non-rainy season, almost every year [8].

\section{Water Quality}

The concerns over India are large and the major problem on people's health is drinking polluted water due to disposal of untreated sewage into the fresh water ecosystem. Further, rivers like the Ganges, Yamuna and Kaveri, flowing through highly urbanized/populated areas, therefore all of them are severely polluted $[13,17,20,21]$. Other water related issues in India is: limited access to safe drinking water and sanitation present major health challenges; dwindling groundwater supplies and a growing population create a pressing need for increased efficiency. These are all the reasons why, in late 2012, U.S. Ambassador for India Timothy Roemer conducted a "Water Issues in India: Opportunities and Challenges" workshop [22]. The workshop dealt with water issues including health and sanitation, ground water depletion, water and energy, water and agriculture, water pollution, water conservation, water recycling and wastewater treatment. The availability of adequate quantity of water is the paramount need for the society. It is true that sustained efforts over the last decade at international level have enabled access to safe drinking water to about one billion additional people in the world. International organizations like World Health Organization (WHO) and the International Bureau of Weights and Measures (IBWM) through its Consultative Committee on Quantity of Matter
(CCQM) have devised standards for ensuring quality of safe drinking water and methodology of achieving the same through a chain of testing and calibration laboratories in each country. For safe drinking water WHO through the efforts of its expert groups has identified nearly 100 contaminants and have specified their safe limits [23-25]. In India the documentary standard of water is the responsibility of the Bureau of Indian Standards (BIS). In which the standard IS 10500 defines the permissible level of contaminants in the water for human consumption [26]. The annual average precipitation in India is about 4,000 BCM. From this, with the state of Indian infrastructure in the recent past the available water resource through the rivers is about 1,869 BCM. Accounting to uneven distribution of rain over the country every year, water resources available for utilization, including ground water, is claimed to be about 1,122 BCM [1]. Much of this water is unsafe, because pollution degrades water quality. Water pollution severely limits the amount of water available to the Indian consumer its industry and its agriculture [27]. The Central Water Commission (CWC) from the Ministry of Water Resources (MoWR) in India is responsible for regulating the use of surface water for irrigation, industry and drinking purposes. The Government of India supplements the efforts of the States by providing financial assistance under the Accelerated Rural Water Supply Program (ARWSP) and from 1991, TheRajiv Gandhi National Drinking Water Mission (RGNDWM) [28] to treat water. The Government of India also seeks international organization coordination. Consequently, some organizations such as bilateral agencies of Japan, the United Kingdom, the United States, Denmark, Sweden, Germany, Australia, Netherlands, and other multilaterals such as the World Bank, WHO, United Nations International Children's Emergency Fund (UNICEF), Water and sanitation programme-South Asia, United Nations Development Programme (UNDP) and the European Union (EU) involve and contribute towards the goal of safe water issues [1].

Although India's economy seems to boom at accelerating rate, most of its growing population still has no access to clean water and sanitation. Because of the rapid increase in the populations, consumption of water also increased. The water quality in India is degraded not only due to a natural cause but also due to over withdrawal of water, poor sanitary conditions in rural and urban areas along with increased applications of fertilizers and persistent organic pollutants (POPs) [13]. Particularly, the quality of surface water resources like rivers, lakes, streams, ponds, wetlands and groundwater sources is a point of major debate. The pollution load on rivers and surface water has increased over the recent years due to rapid urbanization and industrialization $[29,30]$. Furthermore, increasing population, urbanization and growing demand from agriculture as well as industry have brought India's water resources under pressure. In India, consumption of contaminated water, improper disposal of human excreta, lack of personal/food hygiene and improper disposal of solid/liquid waste have been the major causes of diseases. In addition, the waterborne diseases affect education and result in loss of workdays, estimated at 180 million person days/year. Therefore the annual economic loss is estimated to be 1,120 million of Indian Rupees (INR) [1]. Also waterborne diseases put an economic burden on both the household and the nation's economy. Given the diversity of the country and its people, solutions have to be diverse and region specific. In addition, 10 million people are vulnerable to cancers from excessive arsenic and another more than 65 million people are facing risk of fluorosis, now endemic in 17-20 States [6,13,26,31]. Fluorosis is affecting future generations too through pregnant mothers whose anemia is caused by fluorosis. Anemia produces low birth-weight babies who in turn manifest their mother's nutritional deficiencies through physical and 
mental deformities. On the whole, more than 1.6 million habitations in the country are affected by poor water quality. Also it is apparent that large investments in the past did not yield comparable improvements in health and socioeconomic indicators because of the fact that India is one of the major countries where communicable diseases such as AIDS/ HIV, waterborne diseases such as hepatitis-A/B, cholera, jaundice, typhoid is on the increase and tuberculosis and malaria still produce fatal results to higher number of people [6]. Further, chronic and noncommunicable diseases such as heart diseases, diabetes and cancer are also in the steady rise. As indicated earlier, around 38 million peoples are affected by waterborne diseases every year, 1.5 million children are estimated to die of diarrhea alone [1]. In order to reduce such a fatal impact, there must be a definite goal for reducing the withdrawal of fresh water from water sources, by means of water recycling and re-use. Though the government is encouraging water recycling and re-use, it is not implemented effectively in India. At present, even for gardening, vehicle washing, fire protection etc., fresh/potable water is used. More than $70 \%$ of the water drawn from the source is used and let into sewer lines as waste water. If the same is properly treated and recycled then there will be little reduction in drawing the fresh water.

\section{Water Pollution in India}

\section{General}

Water pollution in India can be classified in different ways which is highlighted from the following section. First, bacterial pollution is widespread in India which produce fatal illness of death (through waterborne diseases) of almost 40 million peoples/year [22]. Second, more than $90 \%$ of the sewage generated by rural municipalities and more than $50 \%$ of sewage discharged by urban municipal go untreated and discharged to the fresh water ecosystem [27,32]. Third, industry produces pollutants that are extremely harmful to people, wildlife and the environment. Furthermore several of industrial facilities in India use freshwater to carry away waste from the plant and into rivers, lakes and oceans. Especially, industries produce nearly 31,000 million cubic meters of effluent which is discharged into our fresh water bodies [28]. Fourth, in India, the estimated fecal load is 200,000 tones are generated every day [20]. A fifth, a major cause is the pollution of water from increased fertilizer and pesticide use in agriculture and from industrial sources. The increase in such a usage has degraded the quality of surface water resources by causing nitrate contamination [1]. Sixth, other forms of pollution in India are also a nuclear waste that is produced from industrial, medical and scientific processes that use radioactive material. Mining and refining of uranium and thorium are also causes of marine nuclear waste and its oriented water pollution. The toxic pollutants enter the humans through various routes in which more than $90 \%$ enter into the human body through food and water. Only a small amount of them enter through inhalation of polluted air, dermal exposure, use cosmetics, pharmaceutical, drugs, poor quality herbal formulations, and even items like toys which have paints containing lead.

\section{Fluoride and heavy metals}

Fluoride toxicity due to non-availability of safe drinking water and farming, has become a major public health problem in India. In some parts of India fluoride levels exceeding from $1.0 \mathrm{mg} / \mathrm{l}$ to a maximum of $48 \mathrm{mg} / \mathrm{l}$ [1]. There are thousands of villages in the endemic states in India experience excess fluoride problems. In states such as Andhra Pradesh, Gujarat and Rajasthan, 70-100\% districts contain high fluoride levels in food and water. A black rock salt $\left(\mathrm{CaF}_{2}\right)$ commonly used as flavoring agents by street vendors as well as processed and homemade food which contribute to the major ingestion of fluoride in humans (as it contains $157 \mathrm{ppm})[6,13,26,31]$. Although ingestion of high amounts of fluoride through water and food is the main factor in the causation of endemic fluorosis (e.g., resulting in weak bones, weak teeth, and anemia), other factors such as dietary habits also play a predominant role [26]. In the USA, ingestion of up to $8 \mathrm{ppm}$ fluoride containing water over 15 years did not lead to fluorosis. On the other hand in India levels $>1$ ppm are considered too unsafe. In India, about 200 districts in 17 states India is affected by higher levels of fluoride in subsurface water and groundwater of which Orissa and Rajasthan being the most severely affected. Arsenic (As) contamination was reported in ground water in several parts of the country in which West Bengal is heavily contaminated ( $60 \%$ of the districts are contaminated), affecting 26 million people [33]. The presence of arsenic, a poison and a carcinogen, in the groundwater of the Ganges delta causes health risks to 35-60 million people in West Bengal and Bihar. Researchers have found elevated levels of arsenic in the soil and groundwater near a gold mine in Karnataka (Kiradalli Tanda village of Yadgir district), India [34] The research also highlights health hazards associated (arsenic induced skin disease and cancer) with mining because of arsenic contamination in groundwater found to 30 to 200 times higher than the limit of 10 parts per billion (ppb), prescribed by the WHO [23]. An elevated concentration of total chromium $(\mathrm{Cr})$ and hexavalent chromium $(\mathrm{Cr}-$ IV) is observed in wells in the industrial area in Chennai, Tamil Nadu [35]. The concentration of $\mathrm{Cr}$ in these wells varies between 3 to $250 \mathrm{mg} / \mathrm{l}$ whereas the concentration of Cr-IV ranged from 2 to $210 \mathrm{mg} / \mathrm{l}$ which far exceed the concentration of $0.05 \mathrm{mg} / \mathrm{l}$ prescribed under the Indian standard specification for drinking water quality [26]. In areas where water has high load of minerals like fluoride, arsenic and chromium, alternative sources (canal water, rain water harvesting) would have to be provided not only for drinking water but also in farming. Periodic examination of water quality, particularly for the detection of fluoride, arsenic and chromium is necessary in newer alluvium and floodplain areas in different parts of India. Water supplied by urban municipalities and rural Panchayats should be free of biotic and abiotic toxicant including micro elements and minerals.

\section{Organic and inorganic chemical pollutants}

The antibacterial triclosan (TCS) level in Tamirabarani River, in Tamil Nadu was 940 ppb was an order of magnitude greater than the other rivers particularly, two of the sampling locations contained 3800$5200 \mathrm{ppb}$ which are the highest detected in surface waters. Hazard quotients (HQ) suggested greater environmental risk for TCS in this river [36]. Other research from Chennai, Tamil Nadu coastal areas showed high pollution indices (PI 6.66-14.06) and antibiotic resistance indices (ARI 0.29-0.343). These results indicate that the coastal environment is highly exposed to antibiotic sources [37]. Human health risks associated with microbial vectors are a serious problem on coastal zones, and these risks may increase dramatically in the near future. Another research report from Punjab, India concluded a hotbed of pollution (e.g., Buddha Nullah river run through Ludhiana and Malwa (highly urbanized cities)) before draining into Sutlej River, a tributary of the Indus River, is considered to be a major concern of Indus river pollution $[38,39]$. Calcium (C), magnesium (Mg), fluoride, mercury $(\mathrm{Hg})$, beta-endosulphan and heptachlor pesticide was more than the permissible limit (MPL) on groundwater and tap waters in this region. Furthermore, the concentration of chemical and biochemical oxygen demand (COD/BOD), ammonia $\left(\mathrm{NH}_{3}\right)$, phosphate (PO4 $\left.{ }^{3}\right)$, chloride $\left(\mathrm{Cl}^{-}\right)$, chromium, arsenic and chlorpyrifos pesticide are elevated [39]. The groundwater also contains nickel (Ni) and selenium (Se), while the tap water has high concentrations of lead $(\mathrm{Pb})$, nickel 
$(\mathrm{Ni})$ and cadmium $(\mathrm{Cd})$. Flooding during monsoons worsens India's water pollution problem, as it washes and moves all sorts of solid garbage and contaminated soils into its rivers and wetlands.

Indian National Cancer Registry Programme (NCRP) under the Indian Council of Medical Research conducted a research and reported that "Holy River Ganges" has full of highly poisonous pollutants and communities those living along its banks in Utter Pradesh, Bihar and West Bengal are more prone to cancer [20]. If there is no strict regulation is taken by the government, it would be another Cooum River (Chennai waterways). The worst-hit stretches are east Uttar Pradesh, the floodplains of West Bengal and Bihar. Cancer of the gallbladder, kidneys, food pipe, prostate, liver, kidneys, urinary bladder and skin are common in these parts. Even more frightening news is the finding of gallbladder cancer cases along the river course which is the second highest in the world and prostate cancer highest in the country.Our earlier studies in late 1990's and early 2000's reported high concentrations of pesticides, butyltins, dioxins, PCBs in sediment, fish and Ganges River dolphins [29,30,40,41] which brought a news of "Unholy Ganges" [42]. This is the consequence of years of abuse by industries, domestic waste as well as humans bathing and cremation along the river. The process of disposing of waste has been arbitrary and unscientific.

\section{River Pollution}

\section{Ganges river}

River Ganges originates on southern slopes of Mt. Himalaya especially from the Gangotri glacier at 4,000 m above from sea level. After entering the plains at Hardiwar, it flows through the Bay of Bengal covering over 2,500 km through the provinces of Uttar Pradesh, Bihar and West Bengal (i.e., drains almost eight states of India). Almost, one third of the India's urban population (about 37\%) live in the towns of the Ganges basin. Also about $45 \%$ of the total irrigated areas in India are located in the Ganges River basin. It has been estimated that about $1.4 \times 106 \mathrm{~m}^{3} /$ day of domestic wastewater and $0.26 \times 106 \mathrm{~m}^{3} /$ day of industrial sewage are discharged into this river along with direct disposal of solid waste [20]. Besides, non-point sources of pollution are from the agricultural runoff containing residues of harmful pesticides [39] and fertilizers, animal carcasses and half-burned or unburned human corpses thrown into the river and defecation/mass bathing and ritualistic practices on the banks of the river are common practices. Ganges River contains 60,000 fecal coliform bacteria per $100 \mathrm{ml}$, this value is 120 times more than is considered safe for bathing. Further 4 miles downstream, with inputs from 24 gushing sewers and 60,000 pilgrim bathers, the concentration is 3000 times over the safety limit [43].

The holy Ganges get dirt also from the Kanpur tanneries as a blue stream of the river from beneath the brick factory meet dark ribbon curls down a dirt embankment and flows into the Ganges [44]. Chromium sulfate, used as a leather preservative has been heavily discharged being one of the culprits of cancer, respiratory tract, skin ulcers and renal failure in humans along with arsenic, cadmium, mercury, sulfuric acid $\left(\mathrm{H}_{2} \mathrm{SO}_{4}\right)$, chemical dyes and other macro elements. Any industries in Kanpur along with tannery needed to have a preliminary cleanup before channeling wastewater into a government based industrial effluent treatment plant (IETP), however, several industries ignore the regulation due to the high cost. Other factors such as electrical failure of the IETP breaks down, untreated wastewater spills into the river which is point of other major concern. After a tannery and industrial discharge, few yards upstream, a foul odor to a violent flow of untreated domestic sewage gushing into the river. The bubbling torrent is full of fecal microorganisms responsible for typhoid, cholera and amoebic dysentery. Overall, 10-12 million gallons/day of raw sewage have been pouring out of this drainage. Likewise entire stretch of Ganges River gets polluted [44]. Central Pollution Control Board (CPCB) nationwide survey revealed $66 \%$ of the sample had unacceptable organic values, while $44 \%$ had coliform bacteria. Chemical contamination through over exploitation of groundwater, resulting in excessive iron $(\mathrm{Fe})$, nitrates $\left(\mathrm{NO}_{3}^{-}\right)$, As and fluoride is equally widespread $[12,20,43]$. Arsenic contamination is now grim reality, ironically, in almost the entire Gangetic belt notwithstanding its ample rivers while fluoride contaminated drinking water similarly affects 20 States along Gangetic Plain. Religious beliefs, cultural traditions, poverty, and a large population interactive to cause severe pollution. The Hindu believes in cremating the dead to free the soul and throwing the ashes in the Holy River. Decomposing bodies promote disease and depletes dissolved oxygen. Daily, more than one million Hindus in India bathe, drink, or carry out religious ceremonies in this poisonous river. Due to over pollution in the Ganges over decades, the launch of the Ganga Action Plan (GAP) Phase I initiated in 1985, followed by Phase II in between 1993-1996 which was later merged (in late 1996) with a National River Conservation Plan (NRCP) [19,28]. The NRCP covers polluted stretches of 38 rivers (including Ganges) in 167 towns speared over 20 states in India. The Central Government set up the National Ganga River Basin Authority (NGRBA) under the chairmanship of the Prime Minister, as an empowered planning, financing, monitoring, and coordinating authority to ensure effective abatement of pollution and conservation of the river Ganges by adopting a holistic approach with the river basin as the unit of planning [28].

\section{Yamuna River}

Yamuna River (Ganges River Sub-Basin) was cleaner than Ganges and now is one of the most polluted rivers in the world. Particularly, a 22 kilometer stretch of Delhi urban contributes $70 \%$ of the total pollution load due to inadequate official underground drainage system [7,13-16]. Almost $60 \%$ of city's waste disposal dumped in the river. Further, large parts of the Delhi city inhabits unauthorized illegal colonies and their excreta flows into drains which carry treated and non-treated effluents. Some report reveals in Delhi, legal partially treated effluent mixed with illegal untreated effluent which results in pollution. Treated effluents from Yamuna Vihar treatment plant discharged into the drain, and then drain carries effluents of un-sewered colonies, treated and untreated effluent then picked up at Kondli treatment plant and treated, discharged into drains which carry effluents of unsewered colonies in Delhi and Noida and the results the river remains polluted. The sewage generation from Class-I and II towns has been estimated by the CPCB at 38,254 million liters per day (MLD), out of which only 11,787 MLD is being treated. Therefore, a capacity gap of 26,467 media need to be addressed urgently [28]. Based on Yamuna River the following formula is appropriate; we take water for use, $80 \%$ of water leave as sewage since the city is growing rapidly which make the necessity of more water and eventually we discharge more pollution. Also, if the receiving water body does not have adequate water flow for dilution; the promotion of oxygen demand and increase of bacterial pollution is likely cause of Yamuna River Pollution.

\section{Kaveri River}

Ganges and its Yamuna considered to be mostly polluted in the northern India, River Kaveri (Cauvery in English) ranked first in terms of pollution (most exploited rivers in India by $95 \%$ abstraction of water) in south India [14-16,24]. The River Kaveri originates in 
the Brahmagiri hills of the Western Ghats near Coorg (Thalakaveri), Karnataka state. The Kaveri basin is estimated to be $81,155 \mathrm{~km}^{2}$ with many tributaries. The river basin covers 4 states and Union Territories - Karnataka $\left(34,273 \mathrm{~km}^{2}\right)$, Tamil Nadu $\left(43,856 \mathrm{~km}^{2}\right)$, Kerala $(2,866$ $\left.\mathrm{km}^{2}\right)$ and Puducherry $\left(160 \mathrm{~km}^{2}\right)$. Its total course of $770 \mathrm{~km}$ commands a basin area of 8.8 million hectare mha (56\% in Tamil Nadu, $41 \%$ in Karnataka and 3\% in Kerala and trace in Puducheri Union Territory) [45]. The pollution arises from urban, industries (61 and 1,139 industries, respectively in Karnataka and Tamil Nadu) and agriculture (e.g., fertilizers and pesticides) sectors. The biological oxygen demand (BOD) was severed from the coffee plantation in 3 districts of Karnataka. The practice of washing the dyed fabrics and effluents from textile, sugar factories, tanneries, chemical/engineering units, paper mills still remain unchecked in several districts in Tamil Nadu, adding more pollution to the river that is already too dirty and becoming unfit for human consumption. Also this river becomes an excellent outlet for dumping untreated effluents and all other types of industrial waste. Sources at the Tamil Nadu Pollution Control Board said that they were helpless as they could not monitor the entire river with the existing staff strength. The quantity of wastewater discharged directly into the river is approximately 87,600 cubic meters/ day. The river has a total dissolved solid (TDS) level of $1,450 \mathrm{mg} / 1$ which is three times higher than the permissible limit of $500 \mathrm{mg} / 1$ prescribed by the WHO [46].

\section{Cooum River}

A long time back, Cooum and Adyar river (parallel rivers) in Chennai, Tamil Nadu was a clean crystal clear blue waters, now it is heavily polluted and nothing but a sewage canal which drains into the Bay of Bengal. Cooum flows between Tiruvallur and Chennai districts with the total length of about $72 \mathrm{~km}$. Due to the intense agricultural use of surface water and higher rate of groundwater pumping, leading to reduced base flow in the river, forming of the sandbar at the mouth of the river (Bay of Bengal), discharge of untreated sewage and industrial effluents and encroachment along the banks, the river, become highly polluted. The Tamil Nadu Government proposes several plans and schemes to clean the river but due to drastic Chennai Metropolitan development; converting a clean Cooum is an impossible task at present and also water cannot be re-used particularly for drinking and bathing purpose.

\section{Hot Spot Pollution}

The Indian Government describes the Patancheru Industrial Development Area near Hyderabad as a heavily polluted site [47]. Previous studies show levels of arsenic in ground and surface water that exceed the national drinking water standard. Previous studies report arsenic levels in ground \& surface water in and around Patancheru IDA exceed the WHO and Indian Government Standard $0.01 \mathrm{mg} / \mathrm{l}$. In another recent study, arsenic concentrations in surface water ranged from $0.006-0.1 \mathrm{mg} / \mathrm{l}$, with a mean of $0.3( \pm 0.03) \mathrm{mg} / \mathrm{l}$, while groundwater concentrations ranged from $0.003-1.3 \mathrm{mg} / \mathrm{l}$ with the mean of $0.1( \pm 0.3) \mathrm{mg} / \mathrm{l}$. These results show that arsenic in water consumed by local adults may be associated with both non-cancer and cancer risks $[6,13,33,34]$. There is an urgent need to identify unsafe sources of drinking water in this community and educate residents on the hazard of using them. Furthermore the area is also home to a large number of pharmaceutical manufacturers, the other multiple industrial complex which has resulted in the local river water being the most drugs polluted water in the world [48].

The concentrations of perchlorate in the groundwater samples from India were $<0.005-7700 \mu \mathrm{g} / \mathrm{l}$. The highest levels were found in
Sivakasi followed by Chennai $>$ Trichy $>$ Mumbai $>$ Madurai $>$ Kolkata [49]. Almost $41 \%$ of the analyzed groundwater samples contained perchlorate levels exceeding the proposed guideline for drinking water $(6 \mu \mathrm{g} / \mathrm{l})$, perchlorate salts are inorganic compounds used in explosives and rocket fuel. Human health effects of perchlorate are of public concern because it is known to inhibit iodine uptake by the sodium iodide symporter (NIS) of thyroid gland consequently leading to decrease in the production of thyroid hormones $\left(\mathrm{T}_{4}\right)$ and triiodothyronine $\left(\mathrm{T}_{3}\right)$ [50]. Perchlorate concentrations were compared with the guideline for drinking water in California, USA $(6 \mu \mathrm{g} / \mathrm{l})$. In Sivakasi, Tamil Nadu 22 groundwater samples showed concentrations higher than this guideline level among 54 samples analyzed. Some workers in those factories may use those wells for drinking or cooking purposes and needed to be advised to use alternative water source for their survival [49].

\section{Biological Pollution}

Biochemical oxygen demand (BOD) is the amount of dissolved oxygen in water needed by aerobic biological organisms to break down organic material available in water at a certain temperature over a specific time. Dissolved oxygen (DO) is the amount of oxygen dissolved in water such as a lake, river, or stream. DO is the most important indicator of the health of a water body and its capacity to support a balanced aquatic ecosystem of plants and animals. Based on the studies conducted by $\mathrm{CPCB}$, it is observed that nearly $66 \%$ of the observations recorded are having BOD less than $3 \mathrm{mg} / \mathrm{l}, 19 \%$ between $3-6 \mathrm{mg} / \mathrm{l}$ and $15 \%$ above $6 \mathrm{mg} / \mathrm{l}[7,12,14-16,19]$. Therefore, grossly polluted having BOD $>6 \mathrm{mg} / \mathrm{l}$, moderately polluted having BOD between 3-6 $\mathrm{mg} / \mathrm{l}$ and relatively clean having BOD $<3 \mathrm{mg} / \mathrm{l}$. The very high values of BOD are observed in rivers Sabarmathi $(475 \mathrm{mg} / \mathrm{l})$ downstream of Ahmedabad followed by Godavari $(78 \mathrm{mg} / \mathrm{l})$ down-stream of Nanded city, Satluj (45 mg/l) downstream of Ludhiana city, Yamuna (36 mg/l) downstream of Delhi, Kaveri (27 mg/l) downstream of Tiruchirapalli, Ganges $(17 \mathrm{mg} / \mathrm{l})$ downstream of Varanasi, Krishna and Tapi $(10 \mathrm{mg} / \mathrm{l}$ each) downstream of Sangli and Uphad respectively, Mahanadhi (8 $\mathrm{mg} / \mathrm{l})$ and Brahmani $(6 \mathrm{mg} / \mathrm{l})$ after meeting river Mand and Panposh downstream respectively [12,19].

Open defecation is widespread even in urban areas of India. The presence of coliform suggests that the water is being contaminated with the fecal material of humans, livestocks, pets and other animals. In water, the coliform must be below 104 MPN (most probable number) $/ 100 \mathrm{ml}$, preferably absent from water for it to be considered safe for general human use, and for irrigation where coliform may cause disease outbreak from contaminated water in agriculture. Total coliform and fecal coliform densities in the rivers of India range between 500 to $100,000 \mathrm{MPN} / 100 \mathrm{ml}$. The river Yamuna is leading with highest counts of 2.6 billion MPN/100 ml and 1.7 million MPN/100 $\mathrm{ml}$ respectively, which is followed by Sabarmathi (2.8 million), Ganges (1.1-2.5 million), Brahmaputra (24,000-240,000), Kaveri $(28,000$ 160,000), Brahmini $(60,000-90,000)$, Satluj (3500-35,000), Krishna (10,000-33,300), Mahanadi (17,000-30,000), Baitarni (11,000-22,000) and Godavari (3640-5260) $[8,10,12]$. As far as DO is concern lowest values $(0.1 \mathrm{mg} / \mathrm{l})$ were observed in river Yamuna at the downstream of Delhi, Krishna at Andra Pradesh and Kaveri respectively. While, Sabarmathi showed $0.8 \mathrm{mg} / \mathrm{l}$ at the downstream of Ahmedabad city followed by Mahanadi $(1.4 \mathrm{mg} / \mathrm{l})$ at Sheorinarayan due to discharge of untreated municipal wastewater [12].

\section{Cocktail Chemical Pollution}

Water samples are being analyzed for 28 parameters consisting 
of physicochemical and bacteriological parameters for ambient water samples apart from the field observations. Besides this, 9 trace metals mercury $(\mathrm{Hg})$, arsenic (As), chromium $(\mathrm{Cr})$, cadmium $(\mathrm{Cd})$, lead $(\mathrm{Pb})$, copper $(\mathrm{Cu})$, nickel $(\mathrm{Ni})$, zinc $(\mathrm{Zn})$ and iron $(\mathrm{Fe})$ and 15 pesticides $(\alpha, \beta, \gamma-\mathrm{HCH}, \mathrm{o}, \mathrm{p}$ - and p,p'-DDT, $\alpha, \beta$-endosulphan, aldrin, dieldrin, carbamat, 2-4 D, malathion, methyl parathion, anilophos and choropyriphos are analyzed from the selected samples [12,51]. The monitoring results obtained under the program indicate that organic pollution continues to be the predominant pollution of aquatic resources. In addition to aforesaid chemicals, it is needed to analyze PCBs [29,30], dioxins [29,30], polybrominated diphenyl ethers (PBDEs), perfluorinated organic compounds (PFCs [52]), polychlorinated naphthalenes (PCNs), polycyclic aromatic hydrocarbons (PAHs [53]), short-and medium-chain chlorinated paraffins (SMCCPs), environmental hormones (e.g., bisphenol A, S, nonylphenol and octylphenol), antibacterial chemicals (e.g. TCS and trichlocarbon "TCC" [54]), personal care products (e.g., amines, phthalates) and pharmaceutical chemicals [48] as rapidly industrializing India has shown to contain higher concentrations in some hotspot regions. There is an urgent need to enhance the monitoring network by establishing monitoring stations across all regions and seasonal assessments of all water sources. In case of contamination being detected, an action plan for dealing with sources should be provided.

\section{Water Management}

Overall, the comprehensive objective was to improve the water quality as an immediate short term goal by reducing domestic and industrial wastes from India. The long term objectives are to improve the environmental conditions by reducing all the polluting influences at source. In this instance, the largest sewage treatment plants (STPs) the unanimous choice were to adopt the well-accepted activated sludge process where as trickling filters considered to be suitable for other plants. In case of small towns with enough land however with less wastewater other options such as oxidation ponds can be considered. However, unconventional technologies like the rope bound rotating biological contactors (RBRC), sewage irrigated afforestation, upflow anaerobic sludge blanket (UASB) technology and plants for chromium recovery from tannery wastewater were tried out with a fair degree of success. The most crucial components for preventing river pollution were the main pumping stations which were intercepting the sewage and diverting it to the treatment plants [20]. The most important lesson learned was the need for control of pathogenic contamination in treated effluents. Because the existing levels of depletion and contamination of groundwater resources, which are already over exploited and fairly contaminated, will increase the dependency on the rivers in the future as the only economical source of drinking water.

In India, small industries in unorganized sector contribute to a great deal of pollution (almost $40 \%$ of industrial pollution in India). Common effluent treatment plants (CETPs) are the best remedy for this and therefore, 22 common treatment plants, storage and disposal facilities in 10 states have been established [19]. For a vast rapidly industrializing country like India this number seems to be very small. Furthermore, most plants do not work efficiently. The problem is not only that India lacks sufficient treatment capacity but also that the sewage treatment plants that exist do not operate and are not maintained. Another episode that many of the industries have effluent treatment plants (ETPs) but despite this they did not comply with prescribed pollution standards. Industrial estates normally contain heterogeneous factories belonging to different industries with varying pollution loads and concentrations. Therefore, a stringent regulation such as the introduction of wastewater user fees could be a good tool. Further in order to reduce industrial pollution, the government is also providing tax rebates for the use and implementation of pollution reduction equipment. The Indian experience shows that most of the action for reducing pollution is the result of public interest litigation (PIL) which is evidenced from Lower Bhavani River pollution by South India Viscose Factory in Mettupalayam, India. Therefore, public environmental information disclosure can be an important tool for addressing the environmental problems in India. Effluent discharge tax or fees and treadable effluent discharge permits are the most popular incentive based policy options for reducing industrial pollution. Fees for industrial effluent discharge also help in raising revenues and encourage the polluters to reduce pollution.

In India, municipalities have the treatment capacity only for about $30 \%$ of the wastewater generated in urban areas. In order to improve the water quality in rivers and lakes, there is an urgent need to increase the sewage treatment capacity and its optimum utilization. Investment is needed to bridge the gap between 29,000 million liter/day of sewage India generates, and a treatment capacity of mere 6000 million liter/day [27]. Moreover, as recognized by CPCB (2008) [32], operations and maintenance of existing plants and sewage pumping stations is also very poor. Municipalities lack financial resources and skilled manpower capacity and as a result the existing treatment capacity remains under utilized in a number of cities. India should give emphasis on developing a $100 \%$ treatment capacity up to the secondary level of treatment [14-32]. Treated water can be used for irrigation purposes and for recharging replenishing groundwater. Among the treatment plants, the majority of the government owned sewage treatment plants remain closed most of the time due to improper design or poor maintenance or lack of reliable electricity supply to operate the plants, together with absentee employees and poor management. On the other hand, Indian wastewater treatment plant market has been growing annually at the rate of 10 to $12 \%$. At this rate of expansion, and assuming the government of India continues on its path of reform, major investments in sewage treatment plants and electricity infrastructure development, India will nearly triple its water treatment capacity by 2015 , and treatment capacity supply will match India's daily sewage water treatment requirements by about 2020 . Note also that though India has defined wastewater discharge standards for the domestic and industrial sectors, there are no discharge standards for the pollution emanating from agriculture. Agriculture is the source of non-point water pollution and agricultural water pollution are linked to the use of fertilizers and pesticides. Considering those negative implications, the specific regulation should be implemented for agriculture related discharges.

\section{Conclusions and Suggestions}

In summary, clean, safe and adequate water resources of India constitute a vital asset for the survival of living things and smooth functioning of major systems, and economic development. Because of drastic increase in population and improving lifestyle, heavy pressure is on the call with water resources management since the per capita availability of water resources is reduced at a rapid rate in last 2-3 decades. Increased usage of ground water and surface water resulted in a decrease of water flow in rivers and water level decrease in wells, ponds and lakes. The water quality of surface as well as ground water sources is deteriorating with the alarming rate because of increasing pollutant loads from domestic (rapid population increase and use of 100 's of pharmaceutical and personal care chemical in the house itself), agriculture (increased use of pesticides, fungicides, weedicides 
and fertilizers), tanneries (Chromium) and industrial development (cocktails of chemicals). Apart from pollution, climate change and its oriented global warming are expected to affect rainfall and water resources.

Water resources provide a diversity of services which is vital for human well-being and poverty alleviation. On the other hand, water pollution weakens and deteriorate natural eco-system that supports human health, food production, bio-diversity and industrial growth. It is apparent that Indian peoples intake cocktails of chemicals through polluted water consumption. In some hot spot regions intake of fluorine, arsenic, pesticides and personal care and pharmaceutical chemicals are more than WHO suggested guidelines were observed. The majority of the rivers such as Ganges, Yamuna and Kaveri got polluted with 100 's of the toxic chemicals. Much of this water is unsafe, because pollution degrades water quality and thus severely limits the amount of water available to the Indian consumers. The Central Water Commission (CWC) from the Ministry of Water Resources (MoWR) need to act in regulating the water use with full swing and in a dedicated way. Furthermore, the Central Pollution Control Board (CPCB) and Ministry of Environment and Forests (MoEF) should seek for the more assistance from the Government in order to strictly monitor all the fresh water sources as well as ground water all over the country and to encourage re-functioning of sick sewage treatment plants (STPs) and increase more STPs in all urban sectors.

In India, small industries in unorganized sector contribute to a great deal of pollution. Millions of liters of sewage that originate from industrial, domestic and agricultural waste are discharged into rivers in India (e.g., Ganges, Yamuna and Kaveri). Currently on average (both rural and urban) only $20-30 \%$ of the waste water generated is treated. Common effluent treatment plants (CETPs) and the largest sewage treatment plants (STPs) the needed to construct in big cities and industrial zone along with an activated sludge process where as trickling filters considered for the appropriate plants. In small towns having less wastewater discharge other options such as oxidation ponds can be considered. Nevertheless, STPs specially designed to treat and eliminate bacterial pollution, untreated sewage generated by rural (90\%), and urban (50\%) municipalities, industrial pollutants, fecal load (coliform bacteria), fertilizer/pesticide use and nuclear waste produced from industrial, medical and scientific processes.

In India, despite the concerns relating to water pollution have been addressed, the resources available for prevention of pollution, treatment of polluted water and ecological restoration of polluted water bodies are inadequate. From the monitoring studies by $\mathrm{CPCB}$, $\mathrm{MoEF}$ and universities and institutions it is noted that the most of the rivers and water resources continue to be plagued by the elevated levels of highly toxic inorganic, organic and pharmaceutical chemicals (calcium, magnesium, arsenic, fluoride, mercury, chromium, PCBs, TCS, perchlorate, pharmaceutical chemicals, pesticides such as DDT, cyclodienes, $\beta$-endosulfan, Chloropyrifos, heptachlor, chlordanes, $\mathrm{HCHs}$, dichlofenac, etc.,) low level of oxygen in water(BOD, COD and DO) for aquatic organisms, high fecal coliform bacteria, pathogenic microorganisms (in Ganges and Yamuna), ammonia, phosphate, chloride, nickel, selenium, lead and cadmium from groundwater. Further, the majority of the lakes in India is under severe threat from nutrient overloading and eutrophication and severe weed growth on the water column. Consequently, regular water quality monitoring program needed to be implemented in order to identify the affected areas. Furthermore, movement of pollutants in the rivers, lakes and groundwater aquifers needs to be regulated. In addition, for maintaining the quality of freshwater ecosystems, water quality management plans/ strategies should be implemented.

Besides, the lack of maintenance of rural water supplies and infrastructure is an area of concern. Rainwater harvesting and subsequent recharge of groundwater can help lower the concentration of minerals in aquifers and therefore rain water harvest should be implemented in both central and state governments. In India, investments in community water supply and sanitation projects have increased steadily. However, the health benefits in terms of reduction in waterborne disease have not been commensurate with the investments made. Also it is apparent that large investments in the past did not yield comparable improvements in health and socioeconomic indicators because of the fact that India is one of the major countries where communicable diseases such as AIDS/HIV, waterborne diseases such as hepatitis-A/B, cholera, jaundice, typhoid is on the increase and tuberculosis and malaria still produce fatal results to higher number of people. India often employs standards of safety developed in the western countries. Therefore, questions must come 1) considering the genetic diversity and rampant malnutrition, would these standards apply to India?, 2) What is the safety limit of the toxic chemicals for Indian peoples? (e.g., for safe drinking water WHO's proposed intake safe limits along with Bureau of Indian Standards permissible level of contaminants in the water for human consumption can be adopted), 3) regionally accredited laboratories for analyzing pollutants in various environmental compartments should be set up to help regulatory bodies, 4) creation of public awareness is very important by organizing capacity building and awareness programs for the users and public for encouraging their effective participation in water management practices and developing ethical concepts for making efficient use of water resources and encouraging the government proposed water recycling and re-use (it is not implemented effectively in India), 5) greater interaction between scholars from university and institute, scientists, technologists and media is needed to achieve 6) school education can be a mechanism for creating awareness such as India is at the stage of development transition, wasteful, consumerist, lifestyle which eats up resources and adds to pollution burden should be discouraged, 7) water quality is also affected by floods, road runoff and drought can also arise from lack of awareness and education among the users, 8) sewage treatment plants needed to be build in each municipalities and should be utilized at full capacity and 9) the need for user involvement in maintaining water quality and looking at other aspects like hygiene, environment sanitation, storage and disposal are critical elements to maintain the quality of water resources in India.

\section{References}

1. Gupta S (2012) Drinking Water Quality: A Major Concern in Rural India (Some strategies towards cleaner water and the draft water policy-2012). BARNOLIPIAn Interdisciplinary Journal 1: 2249-2666.

2. Gupta SK, Deshpande RD (2004) Water for India 2050: First order assessment of available options. Curr Sci 86: 1216-1224.

3. Water Resources of India (2013) obtained access at www.nih.ernet.in and http://www.climatechangecentre.net/pdf/WaterResources.pdf in April 2013.

4. Pawar AT, Shelke S, Kakrani VA (2005) Rapid assessment survey of earthquake affected Bhuj block of Kachchh District, Gujarat, India. Indian J Med Sci 59: 488-494.

5. Goel RS (2000) (Editor) Environment Impacts Assessment of Water Resources Projects - Concerns, Policy Issues, Perceptions and Scientific Analysis'. Oxford \& IBH Publishing Company, India, 413.

6. Khurana I, Sen R (2007) Water Aid; Drinking water quality in rural India: Issues and approaches, Background Paper www.wateraid.org.

7. Water Pollution in India (2012) Report No. 21 of 2011-12. 
8. Kumar R, Singh RD, Sharma KD (2005) Water resources of India. Current Science 89: 794-811.

9. Mall RK, Akhilesh G, Ranjeet S, Rathore LS, Singh RS (2006) Water resources and climate change: An Indian Perspective. Curr Sci 90: 1610-1626.

10. CWC (2008) Preliminary Consolidated Report on Effect of Climate Change on Water Resources, Central Water Commission, National Institute of Hydrology, New Delhi June 2008.

11. Murray SJ (2013) Present and future water resources in India: Insights from satellite remote sensing and a dynamic global vegetation model. J Earth Sys Sci 122: 1-13.

12. Bhardwaj RM (2005) Water quality monitoring in India-achievements and constraints. IWG-Environmental International Work Session on Water Statistics, Vienna, June 20-22.

13. Maria A (2003) The Costs of Water Pollution in India. Paper Presented at the conference on Market Development of Water \& Waste Technologies through Environmental Economics, 30th -31st October 2003, New Delhi, India.

14. CPCB (2008) Status of Water Quality in India-2007, Monitoring of Indian Aquatic Resources Series: MINARS/ 29 /2008-2009.

15. CPCB (2010) Status of Water Quality in India-2009, Monitoring of Indian Aquatic Resources Series: MINARS/ /2009-10.

16. CPCB (2011) Status of Water Quality in India-2010, Monitoring of Indian National Aquatic Resources Series: MINARS/ /2010-11

17. MoEF (2012) Performance Audit of Water Pollution in India, Comptroller and Auditor General of India Report No. 21 of 2011-2012.

18. Kumar KS, Kumar PS, Babu MJR, Rao CH (2010) Assessment and mapping of ground water quality using geographical information systems. Int Eng Sci Technol 2: 6035-6046.

19. Murty MN, Kumar S (2011) Water Pollution in India: An economic appraisal.

20. Sharma Y (1997) Case study I-The Ganga, India. In: Water Pollution Control - A Guide to the Use of Water Quality Management Principles (eds) Richard Helmer and Ivanildo Hespanhol, United Nations Environment Programme, the Water Supply \& Sanitation Collaborative Council and the World Health Organization by E. \& F. Spon. 1997 WHO/UNEP ISBN 0419229108

21. Greenstone M Hanna R (2011) Environmental Regulations, Air and Water Pollution, and Infant Mortality in India, July 2011 CEEPR WP 2011-014, A Joint Center of the Department of Economics, MIT Energy Initiative and MIT Sloan School of Management.

22. Neely T (2011) Posted by Tim Neely, March 24, 2011 (posted by the U.S Embassy in New Delhi, India).

23. World Health Organization [WHO] (2007) Guidelines for drinking-water quality, Incorporation First Addendum, Volume 1, Recommendations, Third edition, WHO, Geneva.

24. Grail Research (2009) Water-The India Story March 23, 2009, Copyright (c 2009 by Grail Research, LLC

25. United Nations "Status of Protection of Water Resources, Water Quality and Aquatic Ecosystems in India", Protection of Water Resources, Water Quality and Aquatic Ecosystems in Asia and Pacific, ESCAP, New York. http://www. who.int/water_sanitation_health/resourcesquality/wpcchap2.pdf

26. A Position Paper (2011) Hazardous metals and mineral pollution in India Sources, toxicity, and management. Indian National Science Academy, August 2011.

27. Status of Sewage Treatment in India (2005) Central Pollution Control Board Ministry of Environment \& Forests, Government of India 2005.

28. Report to the People on Environment and Forests 2009-2010 (2010) Ministry of Environment and Forests, Government of India 2010.

29. Senthil Kumar K, Kannan K, Sinha RK, Tanabe S, Giesy JP (1999) Bioaccumulation profiles of polychlorinated biphenyl congeners and organochlorine pesticides in Ganges River dolphins. Environ Toxicol Chem 18: 1511-1520.

30. Kumar KS, Kannan K, Paramasivan ON, Shanmuga Sundaram VP, Nakanish $\mathrm{J}$, et al. (2001) Polychlorinated dibenzo-p-dioxins, dibenzofurans, and polychlorinated biphenyls in human tissues, meat, fish, and wildlife samples from India. Environ Sci Technol 35: 3448-3455.

31. http://fluoridealert.org/health/bone/fluorosis/india.html
32. Indian Water and Wastewater Treatment Market Opportunities for US Companies (2008) Virtus Global Partners 2008.

33. Hoque R (2013) A Study of Awareness about Arsenic Pollution In Rural west Bengal. International Journal of Humanities and Social Science Invention 2 : 43-46.

34. Bhatta A (2012) Arsenic poisoning stalks India's gold mines, South Asia News 12 November 2012.

35. Carol D, Kingsley SJ, Vincent S (2012) Hexavalent Chromium removal from the aqueous solutions by pleurotus ostreatus spent biomass. Int J Eng Sci Technol 4: 7-22.

36. Ramaswamy BR, Shanmugam G, Velu G, Rengarajan B, Larsson DG (2011) GC-MS analysis and ecotoxicological risk assessment of triclosan carbamazepine and parabens in Indian rivers. J Hazard Mater 186: 1586-1593.

37. Vignesh S, Muthukumar K, James RA (2012) Antibiotic resistant pathogens versus human impacts: a study from three eco-regions of the Chennai coast southern India. Mar Pollut Bull 64: 790-800.

38. Prashar (1997) Ludhiana heading for a Bhopal-like tragedy Punjab rivers are now heavily polluted. The Tribune August 1997.

39. Indian Express (2008) Buddha Nullah the toxic vein of Malwa. Indian Express News.

40. Kannan K, Tanabe S, Tatsukawa R, Sinha RK (1994) Biodegradation capacity and residue pattern of organochlorines in Ganges river dolphins from India. Toxicol Environ Chem 42: 249-261.

41. Kannan K, Senthil Kumar K, Sinha RK (1997) Sources and accumulation of butyltin compounds in Ganges River dolphin, Platanista gangetica. Applied Organometallic Chemistry 11: 223-230.

42. Senthil Kumar K (2002) Unholy Ganges under Pesticides Politics. Health and Environment Newsletter 2: 6 .

43. A special report on India (2008) Creaking, groaning: Infrastructure is India's biggest handicap. The Economist News in 11th December 2008.

44. Hammer J (2007) The Holy City of Varanasi; A Deadly Leak, Smithsonian magazine, November 2007

45. World Waterfall Database. Retrieved 9 January and April 2013

46. Agarwal AK, Bay WH, Cosio FG, VanCleef SS, Hebert LA (1999) Seasonal variation in incidence of infection in long term tunneled catheters (LTTC) and Gore-Tex grafts (GG) used as hemodialysis vascular access (HVA). J Am Soc Nephrol 10: 200A.

47. Pokkamthanam AS, Riederer AM, Anchala R (2011) Risk Assessment of Ingestion of Arsenic-Contaminated Water among Adults in Bandlaguda, India $J$ Heath Pollution 1: 8-15

48. Senthil Kumar K (2013) Pharmaceutical Substances in India are a Point of Great Concern? Hydrology and Current Research 3: e103.

49. Sugimoto R, Isobe T, Ramu K, Malarvannan G, Devanathan G, et al. (2012) Fireworks Displays and Production as a Perchlorate Emission Source. In Interdisciplinary Studies on Environmental Chemistry-Environmental Pollution and Ecotoxicology (Eds) Kawaguchi M, Misaki K, Sato H, Yokokawa T, Itai T, Nguyen TM, Ono J, Tanabe S, pp. 279-284.

50. Dohán O, Portulano C, Basquin C, Reyna-Neyra A, Amzel LM, et al. (2007) The $\mathrm{Na}+/ /$ symporter (NIS) mediates electroneutral active transport of the environmental pollutant perchlorate. Proc Natl Acad Sci U S A 104: 20250 20255.

51. Kumar B, Senthil Kumar K, Mahalakshmi PS, Mukhopadhyay D, Shah R (2010) Distribution, partitioning, bioaccumulation potential of heavy metals in water column, sediment and fish muscle from sewage fed fish ponds in eastern Kolkata wetlands, India. Toxicol Environ Chem 92: 243-260.

52. Senthil Kumar K (2005) Fluorinated Organic Chemicals: A Review. Res J Chem Environ 9: 50-79.

53. Guo Y, Senthilkumar K, Alomirah H, Moon HB, Minh TB, et al. (2013) Concentrations and Profiles of Urinary Polycyclic Aromatic Hydrocarbon Metabolites (OH-PAHs) in Several Asian Countries. Environ Sci Technol 47 2932-2938.

54. Kumar KS, Priya SM, Peck AM, Sajwan KS (2010) Mass loadings of triclosan and triclocarbon from four wastewater treatment plants to three rivers and landfill in Savannah, Georgia, USA. Arch Environ Contam Toxicol 58: 275-285. 